\title{
INSPIREE:
}

\section{Decreased Athlete Motor Skills: Before And After Activity Coronavirus Disease (Covid-19) Pandemic}

d.

https://doi.org/10.53905/inspiree.v1i2.6

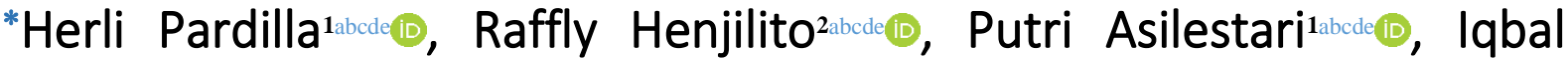 Husnayadi ${ }^{3}$}

${ }^{1}$ Physical Education Education, Universitas Pahlawan (UP) Bangkinang, Indonesia.

${ }^{2}$ Physical Education Department, Islamic University Of Riau (UIR) Pekanbaru, Indonesia.

${ }^{3}$ Department of Shariah and Law, International University of Africa, Sudan.

\section{A B S T R A C T}

A R T I C L E I N F O

The purpose of the study. is study was to look at the impact of pandemic 19 before and after Activity Coronavirus disease (B-A COVID-19P) on the performance of athletes' motor skills (MS)

Materials and methods. The participants (Sample / $\mathrm{N}=40$ ) are national athletes in the Field Jumping category (Triple jump, Long jump and High jump), Riau Province of Indonesia, aged 18-20 years. The test instrument in determining the level of MS in athletes is the Motor Ability Test (7 item test)

Results. The results of the Paired Sample test B-A COVID-19P have sig values. ie 0.00 If seen with a significance standard of 0.05 or $5 \%, p$-values of $0.000<0.05$ and $\mathrm{H}_{1}$ are accepted. This means that there are significant differences between motor skills in B-A COVID-19P.

Conclusions. With the conclusion that MS in track and field athletes there is a decrease in performance after the impact of the Covid-19 pandemic.

Keywords: Motor skills; before and after activity; covid-19p; decreased athlete.

Published: May 27, 2020

\section{INTRODUCTION}

Coronavirus disease pandemic (COVID-19P) has been rapidly spread in Indonesia (World Health Organization, 2020). Indonesia has also been badly hit by SARSCoV-2 infection (Setiati \& Azwar, 2020). Since Covide-19 is greatly affected Indonesian, the government is taking policy steps with regional lockdown in Indonesia. A more stringent confinement of people in high risk areas seems to have a potential to slow down the spread of COVID-19P (Lau et al., 2020). Lockdowns in some areas gave birth to government policies making people in Indonesia implement a social distancing system. Social distancing system is one of the COVID-19P infection prevention and control measures by encouraging athletes to limit visits to crowded places and direct 
contact with others. It was found that every aspect of the sports branch takes precautionary measures by applying Social distancing system mostly. In the case of football, this ended in the postponement of the EURO 2020, one of the largest tournaments world-wide (Muñoz \& Meyer, 2020). Its aim is to keep people apart from each other by confining them to their homes in order to reduce contact rates (Michael Greenstone \& Vishan Nigam, 2020). Communities to accept the need to be physically isolated from each other (Andersen, 2020). Some countries take policy steps to implement Social distancing system in overcoming COVID-19P. SDTas implemented in China during the outbreak, they can reduce peak incidence by $40-60 \%$ and delay the epidemic (Zhang et al., 2020).

The policy for doing exercise at home is instructed to all Indonesian, including athletes. Athletes are forced to carry out training activities at home without getting contact with people and maintaining fitness (Susanto, 2020). Changes in the athlete's training cycle must be adapted to conditions during the pandemic. On the other hand, athletes must maintain (MS) so that performance is maintained well. Athlete's ability to perform at a high level is influenced by inherited (or genetic) abilities in strength, speed, and endurance (Bompa \& Buzzichelli, 2014). This is called motor conditional capacity general physical quality (Pardilla et al., 2019). This is called motor conditional capacity, general physics quality. The effect of exercise on the performance of sports skills has been suggested (Stone \& Oliver, 2009). Fundamental MS can potentially influence in movement and physical activity settings (Robinson, 2010). In this approach, the environment and/or tasks are modified to channel the acquisition of MS (Kamp, Duivenvoorden, Kok, \& Hilvoorde, 2015). in other words, MS in athletes is the most important factor that must be considered in improving athlete performance. The purpose of this study was to determine the decrease in MS during B-A Covid-19P.

\section{Study participants}

The participants were track and field athletes in the Riau Province of Indonesia in the category "Field Jumping" (triple jump, long jump and high jump) aged 18-20 years (Sample / $N=40$ ). 


\section{Study organization}

MS aims to classify and to predict a person in the success of physical activities in track and field sports, jumping categories in particular. Motor Ability / Motor Ability Test / Motor Fitness test consists of Jumping test, Throwing test, Running test and Sit \& Reach (Baumgartner, Jackson, Mahar, \& Rowe, 2006).

Testing procedure.

The MS assessment consisted of 7 test items namely Sprint $30 \mathrm{~m}$ (S30m), Standing Broad jump (SBJ), Triple Jump Standing (STJ), Overhead back throw (OHB), Sprint 150 m (S150m), Shutle Run (STR), and Sit \& Reach (S\&R). Research instruments were selected purposively. The matrix assessment is as follows:

Table 1. Motorik Skills Test For Atlet Track and Field (Jumping kategori)

\begin{tabular}{cllc}
\hline Item Test & \multicolumn{1}{c}{$\begin{array}{c}\text { Motorik Skills Test For Atlet Track and Field } \\
\text { Jumping Test, Throwing test, Running test }\end{array}$} & \\
\hline No & \multicolumn{1}{c}{ Goal Setting } & Category Tes \\
\hline 1. & SBJ & Strenght and explosive leg power & Jumping Test \\
\hline 2. & STJ & Strenght and explosive leg power & Throwing Test \\
\hline 3. & OBT & Strenght and Coordination & Flexibility \\
\hline 4. & S \& R & Flexibility & Running test \\
\hline 5. & S30 m & Stenght and Speed & \\
6. & S150 m & Strange, Speed and Endurance & \\
7. & STR & Speed and Agility &
\end{tabular}

\section{Statistical analysis.}

The final score of each athlete is the calculation of seven motor items. Paired Sample T-test is used to test Hypothesis. A paired difference test is a type of location test that is used when comparing two sets of measurements to assess whether their population means differ (Wikipedia, 2020). Paired test uses the SPSS Version 22 application.

\section{RESULTS}

The result of test during B-A Covid-19P is described descriptively It can be seen in the table below:

Table 2. Deskriptif Statistics Before and After Covid-19 Pandemic

\begin{tabular}{cccccc}
\hline \multicolumn{7}{c}{ Paired Samples Statistics } \\
\hline & Mean & N & Std. Deviation & Std. Erorr Mean \\
\hline Pair 1 & Before Covid-19 Pandemic & 416,5885 & 40 & 29,98780 & 4,74149 \\
& After Covid-19 Pandemic & 387,6690 & 40 & 31,57034 & 4,99171 \\
\hline
\end{tabular}

The out put of paired sample statistics in Table 2 showed that the results of descriptive statistics summary of the two sample values BA Covid-19P with the mean score 
416,5885 before and 387,6690 after Covid-19. look at the test frequency line Ms test results at the time B-A Covid-19P.

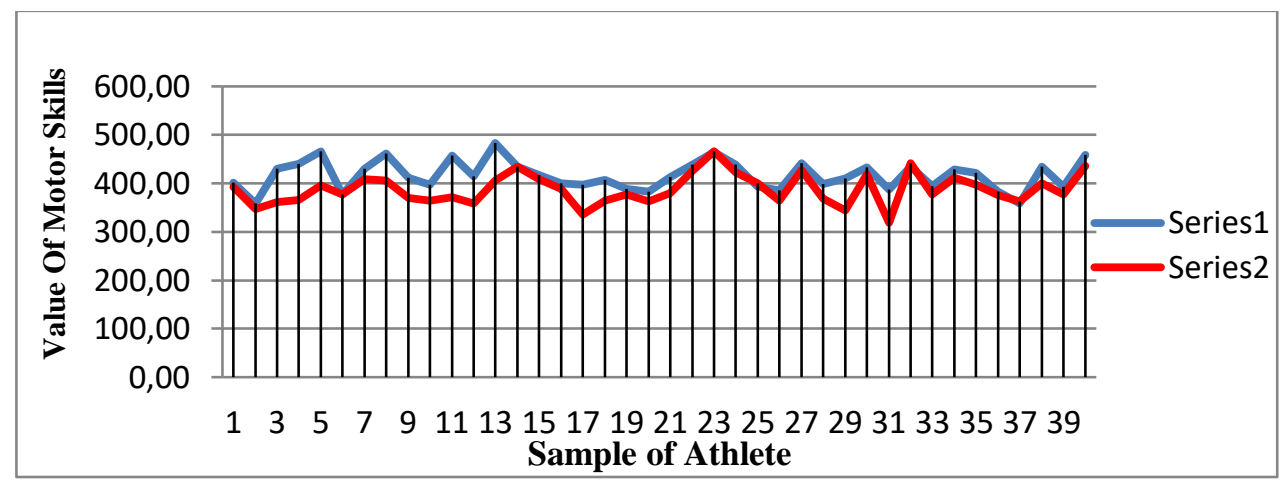

Graph 1. Path constellation analyzes of multiple jump skills

Furthermore, to determine the level of correlation between variables B-A Covid 19P can be seen in table 3 below:

Table 3. Paired Samples Correlations

\begin{tabular}{|c|c|c|c|}
\hline \multicolumn{4}{|c|}{ Paired Samples Correlations } \\
\hline & $\mathrm{N}$ & Correlation & Sig. \\
\hline Pair 1 Before Covid-19 Pandemic \& After Covid-19 Pandemic & 40 &, 635 &, 000 \\
\hline
\end{tabular}

Table 3 showed the level of correlation between B-A Covid-19P using the Pearson Product Momet correlation test. The sig value 0,000 can be interpreted that 0,000 $<0.05$. It can be concluded that there is a significant correlation of MS values between the B-A Covid-19P variables.Furthermore, to know the differentiation level of variable before and After Covid-19 Pandemic variables, in the Paired Sample T-Test there is a hypothesis namely $\mathrm{H} 0: \mu 1=\mu 2$ and $\mathrm{Ha}: \mu 1 \neq \mu 2$. And to see the results of the Paired Sample T-Test using Spss Version 22. On the basis of decision making:

a. If the sig. (2-tailed) $<0.005$, then there is a significant difference between the value of MS between B-A Covid-19P

b. If the value of sig. (2-tailed) $>0.005$, there is no significant difference between the MS values of B-A Covid-19P. Paired test results can be seen in table 3 as follows:

Table 4. Paired Samples Test

\begin{tabular}{|c|c|c|c|c|c|c|c|c|c|}
\hline \multicolumn{10}{|c|}{ Paired Samples Test } \\
\hline & & \multicolumn{5}{|c|}{ Paired Differences } & \multirow{3}{*}{$\mathrm{T}$} & \multirow{3}{*}{ Df } & \multirow{3}{*}{ Sig. (2-tailed) } \\
\hline & & \multirow[t]{2}{*}{ Mean } & \multirow{2}{*}{$\begin{array}{c}\text { Std. } \\
\text { Deviation }\end{array}$} & \multirow{2}{*}{$\begin{array}{l}\text { Std. Error } \\
\text { Mean }\end{array}$} & \multicolumn{2}{|c|}{$\begin{array}{c}\text { 95\% Confidence Interval of } \\
\text { the Difference }\end{array}$} & & & \\
\hline & & & & & Lower & Upper & & & \\
\hline \multirow[t]{2}{*}{ Pair 1} & Before Covid-19 & & & & & & & & \\
\hline & $\begin{array}{l}\text { Pandemic -After } \\
\text { Covid-19 Pandemic }\end{array}$ & 28,9195 & 26,34974 & 4,16626 & 20,49244 & 37,34656 & 6,941 & 39 &, 000 \\
\hline
\end{tabular}


Results of the paired samples test, the sig value is known. (2-tailed) of 0,000. Value of $0,000<0.05$, so it can be concluded that there are significant differences between MS in B-A Covid-19P

\section{DISCUSSION}

The purpose of this study was to identify the impact of BA Covid-19P on MS in the "Field Jumping" athlete (Triple jump, Long jump and High jump). Based on the results of the analysis of research data on the proposed hypothesis, it was stated that there were significant differences between motor skills on BA Covid-19P.

Based on hypothesis testing, (before Versus after) it was found that there is a sig value, (2-tailed) that is 0.00 If it is compared with the significance standard 0.05 or $5 \%$, then the $\mathrm{p}$-value $0,000<0.05$, it means that $\mathrm{H} 0$ is rejected and $\mathrm{H} 1$ is received. It can be concluded that there are differences in the value of MS in track and field athletes "jumping categories" significantly between the value of B-A Covid-19P. With physical activity that maximizes time for training in mastering basic techniques in sports. This was also stated by Stone $\&$ Oliver (2009) that the effect of exercise on the performance of sports skills has been suggested. And in the training process, training methods are needed to help achieve the training objectives, the more appropriate the training methods, the more effective and the training objectives will be achieved (Eka \& Darmawan, 2013)

The MS variable in the track and field athlete category (Jumping) relies heavily on the legs as the main limb in the body. Therefore, the duration of exercise on footwork must be programmed regularly. At rest and after a leg resistance exercise routine to test the influence of exercise on the regulation of muscle protein kinetics (Tipton, An, \& Wolfe, 2020) . This difference could be attributed to the different types of training exercises, durations, and loads used throughout the programs (Gro, Uigan, \& Ettigrew, 2009). Further effects in training also improve performance in body cells. Exercise training may improve endothelial functions (Green, Maiorana, Driscoll, \& Taylor, 2004). The higher his MS, the more skilled he is in carrying out the sport activity itself (Solissa, 2017). 


\section{CONCLUSIONS}

A pandemic Coronavirus disease (COVID-19) is a pandemic greatly affected the world and has become an international pandemic. Conclusions are drawn based on the findings of the Paired sample T-test study which states that there are significant differences between motor skills at B-A Covid-19P. By seeing MS descriptive data on track and field athletes "jumping categories" there is a decrease on athletes performance after being affected by the Covid-19 pandemic. MS's performance is a crucial capability in supporting every sport. It must be considered and becomes a major factor in developing training programs for all athletes in the world. So that the teaching of the sports team has been based on a strategy which puts forward the mastery of motor skills prior to actual involvement in the game, thus putting more emphasis on physical capacities than on the understanding of the game (Grehaigne \& Godbout, 1995).

\section{ACKNOWLEDGEMENT}

Thanks to all those who helped for Universitas Pahlawan, Islamic University of Riau and at International University of Africa.

\section{CONFLICT OF INTEREST}

The author states there is no conflict of interests.

\section{REFERENCES}

Andersen, M. S. (2020). Early Evidence on Social Distancing in Response to COVID-19 in the United, (May). https://doi.org/10.2139/ssrn.3569368

Baumgartner, T. A., Jackson, A. S., Mahar, M. T., \& Rowe, D. A. (2006). Measurement For Evaluation IN Physical Education \& Exercise Science. (E. Barrosse, Ed.). New York: Mc Graw Hill Higher Education.

Bompa, T., \& Buzzichelli, C. (2014). Periodization Training for Sports-3rd Edition (hird Editi). United States Of America: Human Kinetics. Retrieved from https://books.google.com/books?id=Zb7GoAEACAAJ\&pgis=1

Eka, G., \& Darmawan, B. (2013). Perbedaan Pengaruh Metode Latihan Dan Kemampuan Gerak ( Motor Ability) Terhadap Peningkatan Keterampilan Menembak ( Jump Shoot ), 2(2), 239.

Green, D. J., Maiorana, A., Driscoll, G. O., \& Taylor, R. (2004). Effect of exercise training on endothelium-derived nitric oxide function in humans,1,1-25. https://doi.org/10.1113/jphysiol.2004.068197

Andersen, M. S. (2020). Early Evidence on Social Distancing in Response to COVID-19 in the United, (May). https://doi.org/10.2139/ssrn.3569368

Baumgartner, T. A., Jackson, A. S., Mahar, M. T., \& Rowe, D. A. (2006). Measurement For Evaluation IN Physical Education \& Exercise Science. (E. Barrosse, Ed.). New York: Mc Graw Hill Higher Education. 
Bompa, T., \& Buzzichelli, C. (2014). Periodization Training for Sports-3rd Edition (hird Editi). United States Of America: Human Kinetics. Retrieved from https://books.google.com/books?id=Zb7GoAEACAAJ\&pgis=1

Eka, G., \& Darmawan, B. (2013). Perbedaan Pengaruh Metode Latihan Dan Kemampuan Gerak ( Motor Ability) Terhadap Peningkatan Keterampilan Menembak (Jump Shoot ), 2(2), 239.

Green, D. J., Maiorana, A., Driscoll, G. O., \& Taylor, R. (2004). Effect of exercise training on endothelium-derived nitric oxide function in humans, 1,1-25. https://doi.org/10.1113/jphysiol.2004.068197

Grehaigne, J., \& Godbout, P. (1995). Tactical Knowledge in Team Sports From a Constructivist and Cognitivist Perspective. Quest Taylor \& Francis Online, (November).https://doi.org/10.1080/00336297.1995.10484171

Gro, M. E. S., Uigan, M. I. R. M. C. G., \& Ettigrew, S. I. P. (2009). The Effect Of Duration Of Resistance Training Interventions In Children Who Are Overweight Or Obese. Journal of Strength and Conditioning Research 2009 National Strength and Conditioning Association, 23(4), 16-18. Retrieved from https://d1wqtxts1xzle7.cloudfront.net/30765322/article3.pdf

Kamp, J. Van Der, Duivenvoorden, J., Kok, M., \& Hilvoorde, I. Van. (2015). RICYDE. Revista Internacional de Ciencias del Deporte. RICYDE. Revista Internacional de Ciencias Del Deporte, Vol 11(39), 33. https://doi.org/10.5232/ricyde

Lau, H., Khosrawipour, V., Kocbach, P., Schubert, J., Bania, J., Khosrawipour, T., ... Khosrawipour, T. (2020). The positive impact of lockdown in Wuhan on containing the COVID-19 outbreak in China. Journal of Travel Medicine, 27(3). https://doi.org/https://doi.org/10.1093/jtm/taaa037

Michael Greenstone \& Vishan Nigam. (2020). Does Social Distancing Matter? Becker Friedman Institute, 1-20. Retrieved from http://iepecdg.com.br/wpcontent/uploads/2020/04/SSRN-id3561244.pdf

Muñoz, M. D., \& Meyer, T. (2020). Infectious diseases and football - lessons not only from COVID-19. Science and Medicine in Football, 4(2), 85-86. https://doi.org/10.1080/24733938.2020.1749422

Pardilla, H., Hanif, A. S., Humaid, H., Tangkudung, J., \& Bon, A. T. (2019). Model of Triple Jump Achievment: The Andersen, M. S. (2020). Early Evidence on Social Distancing in Response to COVID-19 in the United, (May). https://doi.org/10.2139/ssrn.3569368

Baumgartner, T. A., Jackson, A. S., Mahar, M. T., \& Rowe, D. A. (2006). Measurement For Evaluation IN Physical Education \& Exercise Science. (E. Barrosse, Ed.). New York: Mc Graw Hill Higher Education.

Bompa, T., \& Buzzichelli, C. (2014). Periodization Training for Sports-3rd Edition (hird Editi). United States Of America: Human Kinetics. Retrieved from https://books.google.com/books?id=Zb7GoAEACAAJ\&pgis=1

Eka, G., \& Darmawan, B. (2013). Perbedaan Pengaruh Metode Latihan Dan Kemampuan Gerak ( Motor Ability) Terhadap Peningkatan Keterampilan Menembak (Jump Shoot), 2(2), 239.

Green, D. J., Maiorana, A., Driscoll, G. O., \& Taylor, R. (2004). Effect of exercise training on endothelium-derived nitric oxide function in humans,1,1-25. https://doi.org/10.1113/jphysiol.2004.068197 
Grehaigne, J., \& Godbout, P. (1995). Tactical Knowledge in Team Sports From a Constructivist and Cognitivist Perspective. Quest Taylor \& Francis Online, (November).https://doi.org/10.1080/00336297.1995.10484171

Gro, M. E. S., Uigan, M. I. R. M. C. G., \& Ettigrew, S. I. P. (2009). The Effect Of Duration Of Resistance Training Interventions In Children Who Are Overweight Or Obese. Journal of Strength and Conditioning Research 2009 National Strength and Conditioning Association, 23(4), 16-18. Retrieved from https://d1watxts1xzle7.cloudfront.net/30765322/article3.pdf

Kamp, J. Van Der, Duivenvoorden, J., Kok, M., \& Hilvoorde, I. Van. (2015). RICYDE. Revista Internacional de Ciencias del Deporte. RICYDE. Revista Internacional de Ciencias Del Deporte, Vol 11(39), 33. https://doi.org/10.5232/ricyde

Lau, H., Khosrawipour, V., Kocbach, P., Schubert, J., Bania, J., Khosrawipour, T., ... Khosrawipour, T. (2020). The positive impact of lockdown in Wuhan on containing the COVID-19 outbreak in China. Journal of Travel Medicine, 27(3). https://doi.org/https://doi.org/10.1093/jtm/taaa037

Michael Greenstone \& Vishan Nigam. (2020). Does Social Distancing Matter? Becker Friedman Institute, 1-20. Retrieved from http://iepecdg.com.br/wpcontent/uploads/2020/04/SSRN-id3561244.pdf

Muñoz, M. D., \& Meyer, T. (2020). Infectious diseases and football - lessons not only from COVID-19. Science and Medicine in Football, 4(2), 85-86. https://doi.org/10.1080/24733938.2020.1749422

Pardilla, H., Hanif, A. S., Humaid, H., Tangkudung, J., \& Bon, A. T. (2019). Model of Triple Jump Achievment: The Effect Method Learning and Motor Skills Youth 18 - 20 Age, 2047-2053.

Robinson, L. E. (2010). Child: competence and fundamental motor skills,589-596. https://doi.org/10.1111/j.1365-2214.2010.01187.x

Setiati, S., \& Azwar, M. K. (2020). COVID-19 and Indonesia, (April).

Solissa, J. (2017). Jurnal Menssana, 2(1), 65-73.

Stone, K. J., \& Oliver, J. L. (2009). The Effect of 45 Minutes of Soccer-Specific Exercise on The Effect of 45 Minutes of Soccer-Specific Exercise on the Performance of Soccer Skills, (May 2015). https://doi.org/10.1123/ijspp.4.2.163

Susanto, N. (2020). Pengaruh Virus Covid 19 Terhadap Bidang Olahraga Di Indonesia. Jurnal Stamina, 3, 145-153. Retrieved From Http://Stamina.Ppj.Unp.Ac.Id/Index.Php/Jst/Article/View/491

Tipton, K. D., An, R. W., \& Wolfe, R. (2020). An abundant supply of amino acids enhances metabolic effect of exercise on muscle protein.

Wikipedia. (2020). Paired Difference Test. In Wikipedia. Wikimedia Foundation, Inc. Retrieved from https://en.wikipedia.org/wiki/Paired difference test

World Health Organization. (2020). Coronavirus disease 2019 (COVID-19). Coronavirus Disease 2019 (COVID-19) Situation Report - 72, (April). Retrieved from https://www.who.int/publications-detail/infection-prevention-and-controlduring-health-care-when-novel-coronavirus-(ncov)-infection-is-suspected20200125

Zhang, J., Litvinova, M., Liang, Y., Wang, Y., Wang, W.,Yu, H. (2020). Changes in contact patterns shape the dynamics of the COVID-19 outbreak in China, 8001(April), 113.

Retrieved from 
https://science.sciencemag.org/content/sci/early/2020/05/04/science.abb8001.f ull.pdf 


\section{LAMPIRAN}

\section{Information About The Authors:}

\section{Dr. Herli Pardilla, M.Pd:}

Email: $\quad$ herlipardilla@gmail.com; $\quad$ https://orcid.org/0000-0001-6777-3479; https://www.scopus.com/authid/detail.uri?authorId=57214080181; Department of Physical Education, faculty of Education at Universitas Pahlawan, Indonesia, Tuanku Tambsuai Street, 23, Bangkinang City, 28412, Indonesia.

\section{Dr. Raffly Henjilito, M.Pd:}

Email:rafflyhenjilito@edu.uir.ac.id; https://orcid.org/0000-0003-3804-8950; https://www.scopus.com/authid/detail.uri?authorId=57214072395 ;Departement of Physical Education Health and Recreation, Islamic University of Riau, Indonesia, Kaharuddin Nasution Street, 113, Pekanbaru, 28284, Indonesia.

\section{Putri Asilestari, M.Pd:}

Email: putriasi_lestari@yahoo.com; https://orcid.org/0000-0002-6449-8544 ; English Study Program, faculty of Education at Universitas Pahlawan, Indonesia, Tuanku tambsuai Street, 23, Bangkinang City, 28412, Indonesia.

\section{Iqbal Husnayadi:}

Email: iqbalhusnayadi1999@gmail.com ; https://orcid.org/0000-0002-8292-6864; Department of Shariah and Law, faculty of Syariah at International University of Africa, Madani St. Khartoum 12223, Sudan. 